\title{
Laryngeal complications by orotracheal intubation: Literature review
}

\section{Complicações laringeas por intubação orotraqueal: Revisão da literatura}

\author{
Luiz Alberto Alves Mota', Glauber Barbosa de Cavalho², Valeska Almeida Brito'.
}

1) Master in Surgery for the Federal University of Pernambuco. Professor Assistant of Otolaryngology of the College of Medical Sciences of the University of Pernambuco.

2) Graduating of Medicine of the College of Medical Sciences of the University of Pernambuco. Graduating of Medicine of the College of Medical Sciences of the University of Pernambuco.

3) Graduate Student of Medicine of the College of Medical Sciences of the University of Pernambuco. Graduate Student of Medicine of the College of Medical Sciences of the University of Pernambuco.

Institution: College of Sciences Doctor - University de Pernambuco.

Recife / PE - Brazil

Mailing address: Luiz Alberto Alves Mota - Venezuela Street, 182 - Espinheiro. Zip-code: 52020-170 - Recife - PE - Brazil - E-mail: luizmota10@ hotmail.com Article received in July 22, 2010. Article approved in September 1, 2010.

\section{SUMAMRY}

Introduction: The injuries caused for the orotracheal intubation are common in our way and widely told by literature. Generally the pipe rank of or consequence of its permanence in the aerial ways of the patient is caused by accidents in. It has diverse types of larynx injuries, caused for multiple mechanisms. Objective: To verify, in literature, the main causes of laryngeal complications after- orotracheal intubation and its mechanisms of injury.

Revision of Literature: The searched databases had been LILACS, BIREME and SCIELO. Were updated, books and theses had been used, delimiting itself the period enters 1953 the 2009. The keywords used for the search of articles had been: complications, injuries, larynx, intubation, endotracheal, orotracheal, granulomas, stenosis. 59 references had been selected. The used criteria of inclusion for the choice of articles had been the ones that had shown to the diverse types of injuries caused for the orotracheal intubation and its pathophysiology.

Final Considerations: This revision of literature was motivated by the comment in the practical clinic of a great number of laryngeal sequels in patients submitted to the orotracheal intubation. Of that is ahead important the knowledge, for the professionals of the area of health, the types of complications and its causes, with intention to prevent them, adopting measured of prevention of these injuries.

Keyword: larynx, dysphonia, voice.

\section{RESUMO}

Introdução: As lesões causadas pela intubação orotraqueal são comuns no nosso meio e amplamente relatadas pela literatura. Geralmente são causadas por acidentes na colocação do tubo ou consequência de sua permanência nas vias aéreas do paciente. Há diversos tipos de lesões laríngeas, causadas por múltiplos mecanismos.

Objetivo: Verificar, na literatura, as principais causas de complicações laríngeas pós-intubação orotraqueal e seus mecanismos de lesão.

Revisão de Literatura: As bases de dados pesquisadas foram LILACS, BIREME e SCIELO. Foram utilizados artigos, livros e teses, delimitando-se o período entre 1953 a 2009. As palavras-chaves utilizadas para a busca dos artigos foram: complicações, lesões, laringe, intubação, entubação, endotraqueal, orotraqueal, granulomas, estenose. Foram selecionadas 59 referências. Os critérios de inclusão utilizados para a escolha dos artigos foram os que mostraram os diversos tipos de lesões ocasionadas pela intubação orotraqueal e suas fisiopatologias.

Considerações Finais: Esta revisão de literatura foi motivada pela observação na prática clínica de um grande número de sequelas laríngeas em pacientes submetidos à intubação orotraqueal. Diante disto é importante o conhecimento, pelos profissionais da área de saúde, dos tipos de complicações e de suas causas, com o intuito de evitá-las, adotando medidas de prevenção dessas lesões.

Palavras-chave: laringe, disfonia, voz. 


\section{INTRODUCTION}

The delicate structures of the larynx can be compromised by innumerable causes (1). One of them is the endotracheal intubation.

The endotracheal intubation allows to the ventilation assistance in anaesthetized patients or under ventilation mechanics, being able to be of shortness or long duration. The presence of pipes or nasotracheals in direct contact with the structures of the aerial ways can provoke injuries of mucus, derive from, mainly, of traumatic and drawn out intubations, the use of pipes of great bore and of the raised pressure in the ballonet of probes (2).

The traumatic intubation can occur in emergency situations, that demand rapidity in the access of the aerial ways, in the difficult exposition of glottis or when carried through by professionals inexperienced $(1,2)$.

The complications of the secondary aerial ways to the endotracheal intubation are frequent, even so have diminished significantly in recent years. Many occur with light symptoms and of short duration. However, in many cases the injuries are serious and permanent, involving the structures of the larynx and the trachea, and demand surgery correction $(2,3)$.

The some complications have global incidence varying of $0 \%$ the $18 \%(4,5)$. Prospective study, it found index of $63 \%$ of acute injuries of the larynx in patients submitted to the orotracheal intubation and that they had been reversible in 30 days (6).

Due to configuration of glottis in "V", the main injuries occur in the posterior portion of the larynx, in the vocal processes, where the sounding lead meets in close contact with the mucous, being able to result in ulceration of the region that involves the epithelium of the interarytenoid mucous, healing with fibrosis and setting of the arytenoids cartilages in the median line, simulating picture of bilateral paralysis of the folds vocals (2).

Diverse types of larynx and windpipes, secondary injuries to the endotracheal intubation, have been described (7). Soon in the introduction of the cannula for it verbal via, during the attempts of exposition of glottis with the laryngoscope, are described, extractions, injury of lip, language and pharynx vocal lacerations in epiglottis, folds, esophagus and trachea, hematomas and accession of vocal folds, displacement and strain of arytenoids cartilages (8). With the time complications occur as frostbite of mucous, stricture and granulomas $(1,2)$. In the pathophysiology of these injuries, the ischemia of the mucous is the common denominator, particularly for the use of tracheal pipes of bigger diameter and for the raised intracuff pressure (7).

The factors of risk for the endotracheal afterintubations complications are of three types: factors related to the patient, related with the requirements technician to reach and to keep the intubation, and factors related to medic (3).

Between the factors of risk related the patient include age, because the mucous larynx if become more fragile with the age and are more susceptible injury (9), history of intubation and tobbaco (10).

Between the risk factors associates with conditions techniques to reach and to keep the intubation met it drawn out duration of intubation (the risk of complications increases with the duration of the intubation) $(8,9)$, the size of endotracheal pipe (in particular sounding leads whose size is bigger or equal the 8 they would result in more complications of what the sounding leads lesser bore) $(8,11)$ agitation of the patient (especially extubationreintubation episodes), bad positioning of the sounding lead (placed very high or very below of glottis, with a balloon located in the ring cricoids) poor humidification of inspired air and the infection local $(8,9)$.

Finally, between the related factors of risk with the doctor, are the lack of experience and the difficulty of rank of the endotracheal pipe in the appropriated place (9).

Currently with more necessary diagnostic techniques we can confirm the illness with more security. In these cases, the examination videolaryngostroboscopy and the electromyography of the vocal muscle are decisive in the clarification of diagnstic $(12,13)$.

This revision of literature was motivated by the comment in the practical clinic of a great number of laryngeal aftermaths in patients submitted to the orotracheal intubation. Of that is ahead important the knowledge, for the professionals of the area of health, the types of complications and its causes, with intention to prevent them, adopting measured of prevention of these injuries.

\section{LiteraURe REVIEW}

This study of literature revision it was carried through by means of gotten bibliographical research through the BIREME, LILACS and SCIELO databases. Articles, books had been used and thesis, delimiting itself the period enters 1953 the 2009. The keywords used for the search of articles had been: complications, injuries, larynx, intubation, endotracheal, orotracheal, granulomas, stenosis. 59 
references had been selected. The used criteria of inclusion for the choice of articles had been the ones that had shown to the diverse types of injuries caused for the orotracheal intubation and its pathophysiology.

\section{DISCUSSION}

\section{Symptoms}

The laryngeal symptoms are disturbances of the speech or complaints related to the aerial ways. The disturbances of the speech can be told or be perceived by the professional listeneras dysphonia or hoarseness, whisper, complete aphony, vocal fatigue and incapacity to support the speech and the volume adequately. Other symptoms can include pain of throat, fullness and sensation of strange body in the throat. The majority of these phonatory symptoms is supported by an increase in the disturbance parameters that reflect in variations in the intensity and frequency in the vibration of the vocal folds (14-16).

The pharyngolaryngotracheal symptoms as pains of throat, difficulty to speak, cough, increase of secretions, pain to swallow, are also common in the one post-surgical (1).

In relation to the phonatory symptoms, it is important to notice that they auto are limited and disappear inside of 24 the 48 hours. When become persistent for more than 72 hours, the anesthesiologist must suspect of injury of the vocal folds. When the phonatory symptoms are followed of infirmity of aerial ways, as stridor, dyspneia or aspiration, the injury in the cricoaritenoid joint is suggestive and is important that if it makes an evaluation of the aerial superior ways (17).

\section{Factors Associated}

Great part of the larynx injuries after-intubation if decides spontaneously, for the capacity of regeneration of the epithelium. However, in determined circumstances that take to the aggravation of the tissue perfusion and deficient healing, the evolution of this process can aggravate and originate laryngeal injuries of changeable gravity, as it occurs in weak patients, diabetic, with hemodynamic alterations or systemic infections (1).

Some factors are suggested for the formation of granulomas: the adult, feminine sort, anemia age, hypotension, malnutrition, respiratory infection, diabetes mellitus and other fellow creatures to the predisposing and/or triggering factors in general way $(18,19)$.
It was observed that the risk and the incidence of paralysis of the vocal folds had increased with the age and was three times bigger in patients with age between 5069 years. The risk also duplicated in patients who had as comorbidity, diabetes mellitus and arterial hypertension (20).

The fact of diabetes mellitus to be associated with peripheral neuropathy can increase the susceptibility to the paralysis of the vocal folds (21). On the other hand, the arterial hypertension is associated the atherosclerotic alterations arterial of the larynx. Associated to this, the insufficiency of the microcirculation in the recurrent laryngeal nerve also can be caused by compression mechanics for the ballonet of the tracheal pipe. Therefore, the recurrent nerve and its peripheral ramifications, muscles and fabrics of the larynx can be more vulnerable the mechanical damages and to the pressure of the cuff of the tracheal pipe in patients with diabetes mellitus and hypertension of what in others patients (20).

\section{Relation with the time}

In a generalized manner, drawn out time is considered the superior periods the 24 or 48 hours of orotracheal intubation, varying between some studies (22-24).

The constant movements of the neck, carried through for the patient in agitation state, provoke friction of the sounding lead and its ballonet throughout the respiratory treatment. In the patient without sedation reflected movements of deglutition and fouling of the vocal folds are gifts also on the tracheal pipe. Thus, how much bigger the time of the intubation greater is the risk of occurrence of these injuries (2).

Were verified $2 \%$ of stenosis of the larynx in patients with orotracheal intubation between three and five days and $5 \%$ of stenosis of the larynx with orotracheal intubation between six and ten days. This study it showed that the gravity of the larynx illness directly was related to the duration of the orotracheal intubation (25). In 73 patients, in which was carried the tracheotomy in 6th day of orotracheal intubation, one evidenced that the lesser time of exposition of the larynx to the trauma of the orotracheal cannula seems to cause few complications (26).

The risk and the incidence of paralysis of the vocal folds had increased with the duration of the intubation. The risk was folded for duration of the orotracheal intubation between 3-6 hours and was seven times bigger for duration between 6-9 hours (20). The relation between the drawn out intubation and an increase of the risk of immobility of the vocal folds was clear in before studies $(11,27)$. 
In the case of granulomas, even so they occur, more commonly, in intubations drawn out, also had been diagnosised in intubated patients for short period of time. This leads to believe that the intubation time does not seem to be the only determinative factor for the appearance of lesion (7). The fact of that some patients develop granulomas exactly after few hours of intubation, also was detached by others authors $(28,29)$.

\section{Relation with the tube size}

The inadequate diameter of the intubation sounding leads and the difficulty in keeping immobilized the intubated patient are predisposing factors to the development of injuries of aerial ways. Thus, the choice of the diameter of the cannula is an aspect important to be considered, a time that, for the configuration of glottis in $\mathrm{V}$, the posterior portion of the larynx keeps soul contact with it. To if using tracheal cannula more calibrous, this region suffers the consequences from the ischemia caused for its compression on the mucous. In these conditions, one soon observes necrosis and superficial ulceration of the mucosa after extubation $(1,2)$.

\section{Relation with the pressure}

When if they use tracheal cannula with ballonet, sends regards that the pressure in its interior if keeps inferior to the one of the pressure of hair perfusion, that is, minor who $30 \mathrm{cmH} 2 \mathrm{O}(30,31)$.

Experimental study in intubated rats was become fulfilled, varying the pressure in the ballonet of 20 the 100 $\mathrm{mmHg}$. This was evidenced that the sprouting of injuries directly was related to the rise of the pressure in the interior of the ballonet, especially when exceeds the pressure of hair perfusion $(25 \mathrm{mmHg})$, generating, sequentially, ischemia on the mucous, damage to the sanguineous supplement for the perichondrium, local ulceration, secondary settling of bacteria and chondritis (30).

On the other hand, after histological analysis of the tracheal mucous of dogs in the place of contact with the ballonet, observed when comparative epithelial injuries to the normal respiratory epithelial, as areas of superficial erosion and eyelash falls, exactly with the use of only 13 pressures of $\mathrm{cmH} 2 \mathrm{O}$ (31). It is standed out that great part of these injuries if decides spontaneously, for the capacity of regeneration of epithelial (32).

The measure of the pressure of the ballonet is not carried through routinely in the surgical center or the units of therapy intensiva (2). The great importance of the monitoring of the pressure in the interior of the ballonet comes being evidenced for some authors, for being simple maneuver, of low cost, carried through with digital manometer portable $(31,33)$.

\section{Edema}

The space of Reinke, the superficial layer of the proper blade of the vocal fold, is crucial for the vibration of the vocal folds. The endolaring breaking, of this structural layer, for the aggressive intubation, can result in edema of the vocal folds, hindering, due to rigidity of the vocal fold, the perfect wavelike movement it mucous, consequently leading to an alteration in the phonatory quality. For low the lymphatic draining, the resorption of edema that it occupies this space of Reinke can be slow, what it would make it difficult the vocal recovery, being able to become the persistent dysphonia $(1,17)$.

\section{Ulcer}

The classic "ulcer of contact" was originally described for Chevalier Jackson, whom it affirms to be caused by the high pressures exerted for the pipe against the posterior part of the larynx and due to mechanic abrasion (34).

In a sample of 82 patients, one met 77 patients (94\%) with some laryngeal damage in the initial laryngoscopy. Of these 76 (98.7\%) had presented ulceration in the mucous in the posterior portion of both true the vocal folds. Exactly the area where the tracheal pipe makes direct contact with larynx (4).

It was verified that the ulcer proceeds to the appearance of laryngeal granuloma (26).

\section{Laceration}

The laceration of vocal fold, constituted of a direct glottis injury, is cause of vocal consequences and occurs frequent when a intubation in emergency conditions is effected, it are of the structures of reanimation or surgical block. Moreover, some factors of risk can be related to the occurrence of laceration in the vocal fold: inexpertly of the professional, difficulty in displaying the anatomy of the patient, use of sounding leads of bore more raised in a patient with inadequate relaxation of its glottis (8).

The healing of the lacerations of mucosa of the larynx can occur to the cost of tacks and fibroses. When if they install in the previous commissure of glottis promote great damage of the voice, for compromising the phonatory 
portion. Already the cicatricial processes that involve the posterior portion of glottis can determine nip of the glottic light, generating symptoms as dyspnea and weak and weak voice. It has situations where the arytenoids muscles are injured and fibrosis that form in this place hinders the complete abduction them vocal folds, which if keep in the medium region, simulating paralysis larynx picture (1).

The lacerations that reach the layers deepest of the proper blade and the vocal ligament mainly harm the wavelike movement of mucous, modifying the vocal quality and hindering the modulation of voice (1).

\section{Cartilaginous Trauma}

The arytenoids cartilages are more vulnerable to the traumas of intubation for being located in the posterior region of glottis. The aggressive orotracheal intubation with a pipe of inadequate diameter or when the endotracheal pipe is inserted, while the vocal folds are still in the medium position, can damage both the vocal folds and the cricoaritenoid joints. In the same way, the removal of the endotracheal, concomitant pipe the cough can dislodge arytenoids and still result in one glottis incompetente $(15,35)$. These sub-dislocations cause asymmetries of the vocal folds and its movements. Some patients with larynx asymmetries develop secondary injuries, as the vocal nodules, had to the constant muscular compensations during the speech (1).

\section{Dysphonia}

One of the symptoms most frequent presented by the patients in the postoperative period is the hoarseness, that can be present in $14,4 \%$ to $50 \%$ of the patients submitted to the orotracheal intubation. Its frequency if must to the raised incidence of laryngeal injuries during the orotracheal intubation, mainly when carried through without the choke neuromuscular $(36,37)$. This symptom, in the great majority of the times, is temporary, lasting on average the two three days. However, in $10 \%$ of the cases the hoarseness becomes permanent, modifying the quality of life of the patient who had normal voice before the surgery (1).

The majority of the injuries are caused by the direct injury on the vocal folds, causing edema or ulcerations or for alteration of the mobility of the cricoaritenoid joint and for the effect of mold caused for the translarynx cannula. Such effect disappears, most of the time, with the regression of the inflammatory process (35).

Dysphonia and after-decannulation bronchoaspiration result, habitually, of the limitation of the fouling of the vocal folds. When recovery of the mobility of the cricoaritenoid joint exists and the effect of mold for the cannula subsides, have the return of the voice and the control of the bronchoaspiration to normal (26).

\section{Dysphagia}

The drawn out orotracheal intubation can provide to injuries in the verbal socket, pharynx and larynx, that cause reduction of the motor patterns and local sensitivity and compromise the process of the deglutition, determining the oropharyngeal dysphagia. These can unchain problems as the malnutrition and the aspiratory pneumonia, getting worse significantly the clinical state of the hospitalized patient (38).

It was demonstrated that patient submitted to the orotracheal intubation they present alterations in pharynx the verbal phase and of the deglutition, frequently followed of larynx penetration and aspiration, being common the presence of more than an alteration for each evaluated adult, determining lack of functionality in the process of the deglutition. Moreover, the functions related to these structures, as the breath, says and the deglutition to it, is not carried through during the institution of the orotracheal intubation, propitiating reduction of the larynx function and consequent inactivity of the musculature in the period of its utilization (4).

\section{Paresis and paralysis of vocal preach}

The incidence of paralysis of vocal fold varies of $1 \%$ (39) the $37 \%$ (27). This discrepancy exists because some classify as paralysis the paresis orotracheal after-intubation (7).

Paresis of the vocal folds is the reduction in varied degree of the mobility of the vocal folds, separately or not, caused for the direct trauma of the endotracheal cannula, mucous or muscularalterations or alteration of the mobility of the cricoaritenoid joint. The paresis after-intubation is, most of the time, transitory, returning the vocal folds to normal after the regression from the inflammatory alterations (40).

When the consequent injury to the orotracheal intubation if extends to the intrinsic muscles of the larynx, can unchain paresis or paralyses of the vocal, temporary or definitive folds. The paralysis or setting of the vocal folds is frequently unilateral, but it can be bilateral. Respiratory insufficiency can be presented after as stridor and up to six hours the decannulation. The unilateral paralyses harm the vocal emission sufficiently; therefore the paralyzed vocal fold is located more laterally than the healthy one hindering 
the perfect contact between them during the speech. In these conditions, the voice becomes weak and weak, resulting in fatigue and exhausting muscular effort during the speech. In the bilateral paralyses the respiratory symptoms of dyspneia predominate a time that both the vocal folds are hindered of if abducting. In these cases, the voice is little commited $(1,26)$.

Moreover, the induced larynx dysfunction for the orotracheal intubation can premake use the patients to the aspiration after-extubaton (14), factor of risk for pneumonia, what it would increase the postoperative morbidity and mortality.

It is probable that the paralysis of the vocal folds after the intubation has origin in damages to the nerves caused for the compression of the microcirculation, affecting the nerves of the larynx. It has some possible mechanisms for this: the tracheal pipe can cause acute inflammation in the larynx, that is, erythema, ulceration and granulomas, and these pathological changes can induce to the vocal paralysis; the pressure of the ballonet of the endotracheal pipe could potentially compress the recurrent nerve and its peripheral branches in the larynx, causing degeneration and sub-paralysis of the nerve. This insufficient microcirculation for the supplying of the recurrent nerve and its peripheral ramifications, due to compression mechanics of the ballonet, can cause ischemia and neuronal degeneration e, subsequently, paralysis and immobility of the vocal folds (20).

The translarynx pipe can also cause sensorial denervation of the larynx for the constant pressure (14), compromising the normal protection of the laryngeal mechanisms and eliminating the reflected arc that mediates the phase of the laryngeal abduction the muscular function of pharynx (42).

It was observed that the left vocal fold showed to be two more vulnerable times to the paralysis of what the right vocal fold. This can occur due to insertion of the pipe, the right for left, and to the setting of the tracheal pipe in the right angle of the mouth, what it would more injure it with frequency (20).

Studies using the eletromyogram (EMG) to test laryngeal the nerve inferior, in the occurrence of immobility of the larynx after-intubation, did not disclose parcel neurogenic (noalteration of the conduction of the nerve or potentials of denervation) (43). For the fact of that the innevartion of the larynx is complex, the presence of a normal EMG necessarily does not mean to conclude that it has absence of abnormalities of nerve (8). The paralysis is accepted for the majority of the authors as of origin purely mecanic (43).

\section{Polyp}

After the extubation, the frustrate and overwhelming attempts of the patient in emitting the voice of "more clean" form, unchains muscular efforts adds and tension of the cervical musculature and the larynx. This inadequate standard of speech can become habitual and the traumatic and constant impact of the vocal folds during speaks will give to origin the secondary injuries on the mucous covering of the larynx, as the vocals polyps.

\section{Granulomas}

Granulomas are rounded off injuries, of diverse unilateral or bilateral colorations (rosy, whitish or wine), most of the time pediculated, presenting itself with smooth or irregular surface. Its pedicles of implantation if insert in the posterior of glottis, especially to the level of the vocal apophysis, local region where the cannula keeps soul contact with the mucosa of larynx (7).

It was observed enters the main etiologies, the vocal abuse (33.3\%), gastroesophageal reflux (30.3\%), the orotracheal intubation (22.7\%) and idiopathic origin (9\%) (44).

Granulomasare, in general, a unspecificinflammatory process formed by fabric of granulation (45). The healing of the larynx that if carries through for second intention complex and is influenced by constant movement of nip and expansion of this, occurred during the breath, speech and deglutition. The repairing of the ulcers of the epithelium is initiated in the basal membrane when she is unbroken. However, if this was destroyed, the healing process is slow, initiating from the edges of the fabric ulcerated (46).

The vocal symptoms after appear the 15 to 20 days of the removal of the tracheal pipe, however when small they cannot cause symptoms. When experience symptoms implant in the previous phonatory glottic portion cause damage to the vocal emission (1). Os add include sensation of strange body, cough, cough and pain in the topography of larynx (7).

The occurrence of granulomas has fort predominance in the masculine sort, except in the cases of after-intubation. In a sampling group of 66 laryngeal patients with granulomas, of which 15 if had developed intubation after, of these, six belonged to masculine sort and nine to female sort (44). To explain this fact, we can evoke the larynx configuration of the woman, who presents minors consequently dimensions and, allows to a bigger contact of the cannula with the mucosa of the aereal ways $(12,47)$. Moreover, the fragile perichondrium that recovers the vocal apophysis of the 
arytenoids cartilages and the poor vascularization of the local mucous is factors adds that they become the region most vulnerable the traumas of intubation (7).

Granulomas of larynx endotracheal after-intubation is one of the complications most common, varying between $26,7 \%$ (26) and 44\% (11). Its appearance occurs in about 21 days, while it approximately has spontaneous regression in a period of three months, in the majority of cases $(6,11,26)$.

The diagnosis is made through anamneses, otolaryngologic examination, videolaryngoscopy, videolaryngostroboscopy or even though for the indirect laryngoscopy (48).

As in the cases after-intubation the causal factor of granulomas it is not perpetuated, generally its spontaneous regression is observed, or by means of aggressive phototherapy or still resolution after surgical removal, in general carried through in most voluminous or the bilateral cases (44).

The botulinum toxin injection in the larynx is a great advance in the treatment of granulomas, being a safe and efficient procedure and that it can be used in the cases that do not answer to the clinic treatment.

\section{Stenosis larynx}

Important cause of hoarseness after the extubation, larynx stenosis is one of most frightful. All the boarded factors can contribute for its sprouting. Beyond the serious vocal commitment, the patient presents intense dyspneia. In centers exactly considered of excellence in intensive cares, the occurrence of stenosis of larynx for orotracheal intubation varies of $0,5 \%$ (4) the $14 \%(50)$.

In the practical clinic, the majority of the patients who presents with stenosis tracheal after-intubation possess mature fibrotic scars, with minimum evidence of inflammation of the aerial ways. These patients had been typically submitted to the intubation in a relatively distant past, and some of them could have been treat for asthma before the correct diagnosis. The precocious phase of stenosis tracheal after-intubation is characterized by ulceration of the mucosa and perichondritis, followed for exophytic granulation fabricformation. Later, the granulation fabric gradually is substituted by a mature fibrotic scar, that if contracts and originates the classic injury of estenosis ( 40 , $51,52)$.

With the intubation the use of techniques of closed ventilation is common, being the cannula in narrow contact with the subglottic wall. This region is narrowest of the superior aerial ways, becoming, therefore, most susceptible to injure the contact to it with rigid cannula. This contact takes edema of mucosa and hyperemia, stasis of secretion and local infection, being able to develop itself, later, weaved of granulation and necrosis. When of the withdrawal of the cannula, intubation after drawn out, the wall of the subglottic region already is in healing phase, with collagen formation that, after the maturation, is contracted circumferentially, being able to provoke partial or complete stenosis $(50,53)$.

When these alterations evolve for subglottic stenosis, almost always, in children, become fulfilled it tracheotomy. This propitiates to the medical time for the evaluation and for the definitive behavior but, during this interval of time, it becomes the daily routine of the difficult tracheotomizated patient and traumatic (54). Beyond it, stenosis demands cares that can involve multiple endoscopy, endoscopic dilatations, endoscopic resections, cryosirurgical, laser resections, tracheoplasty, graft of cartilage and cricotracheal resections, with the treatment if extending for months or years, needing, to the times, even of definitive tracheotomy (55-59).

\section{FinAL CONSIDERATIONS}

The breath by means of a endotracheal pipe is not physiological, however essential, in many situations. The causes of larynx complications orotracheal after-intubation are very diverse, as well as its gravity. The knowledge of the conditions of the related aerial ways to the intubation and the agreement of its pathophysiology and of the main predisposing factors assists in the adoption of writs of prevention that will assist in the reduction of these injuries.

Some simple writs of prevention can be adopted during the attendance the intubated patient which guarantees the reduction in the index of conditions of the aerial ways. Care and ability in the introduction of the pipe, choice of the ideal size, use of pipes with balloons more malleable and complacent, adequate immobilization of the patients, to use chokes neuromuscularbefore the orotracheal intubation, well-taken care of ballonet in the tracheal aspiration, constant monitoring of the pressure in the interior of the ballonet are some of the measures that can assist in the prevention of larynx complications.

The patients with acute respiratory insufficiency that if makes necessary the orotracheal intubation associate to the ventilation mechanics, many times are sedated for better adaptation to this type of assistance. Ahead of the knowledge of the possible sequels after-intubation, the awareness of the UTI team is important and the care in the 
handling in the occasion of it weans of the ventilation mechanics more soon possible, a time that how much bigger the time of bigger intubation the risk of complications. Alerting that in the cases of impossibility of it weans it, it must be thought about the possibility to carry through the tracheotomy and its hesitation will be able to cause the complications orotracheal after-intubation.

When it will have injuries of great extension in the larynx, not if it must doubt the decision for the precocious tracheotomy, removing of the injured mucosa the contact of the tracheal pipe, propitiating, thus, epithelial regeneration.

The orientation for the accomplishment of vocal and larynx evaluation in the patients submitted to the orotracheal intubation, would have to be routine from the high one of the UTI. With this measure it would have the precocious diagnosis of the larynxes and tracheal complications.

\section{BIBLIOGRAPHIC REFERENCES}

1. Martins RHG, BrazJRC, Dias NH, Castilho EC, Braz LG, Camacho Navarro LH. Rouquidão após intubação traqueal. Rev Bras de Anestesiol. 2006, 56(2):189-99.

2. Martins RHG, DiasNH, BrazJRC, CastilhoEC.Complicações das vias aéreas relacionadas à intubação endotraqueal. Rev Bras Otorrinolaringol. 2004, 70(5):671-7.

3. Pons Y, Conessa C, Ouraini S, Clement P, Roguet E, Poncet Jl. Complications laryngo-trachéales post-intubation atypiques: à propos de 3 cas. Rev Laryngol Otol Rhinol. 2009, 130(2):129-32.

4. Colice GL, Stukel TA, Dain B. Laryngeal complications of prolonged intubation. Chest. 1989, 96:877-883.

5. Woo P, Kelly G, Kirshner P. Airway complications in the head injured. Laryngoscope. 1989, 99:725-731.

6. Lindholm CE. Prolonged endotracheal intubation. A clinical investigation with special reference to its consequences for the larynx and trachea and to its place an alternative to intubation through a tracheostomy. Acta Anaesthesiol Scand. 1969, 33:1-131.

7. Martins RHG, Dias NH, Santos DC, Fabro AT, Braz JRC. Aspectos clínicos, histológicos e de microscopia eletrônica dos granulomas de intubação das pregas vocais. Rev Bras Otorrinolaringol. 2009, 75(1):116-22.

8. Lacau Saint Guily J, Boisson-Bertrand D, Monnier P. Lésions liées à l'intubation oro- et nasotrachéale et aux techniques alternatives: lèvres, cavités buccale et nasales, pharynx, larynx, trachée, oesophage. Annales Françaises d'Anesthésie et de Réanimation. 2003, 22:81-96.

9. Laccourreye L, Perie S, Monceaux G, Angelard B, Lacau Saint Guily J. Traumatismes iatrogènes du larynx et de la trachée. EMC Oto-Rhino-Laryngologie. 1998, 20:720-30.

10. Lundy DS, Casiano RR, Shatz D, Reisberg M, Xue JW. Laryngeal injuries after short-versus long-term intubation.J Voice. 1998, 12(3):360-5.

11. Santos PM, Afrassiabi A, Weymuller Jr EA. Risk factors associated with prolonged intubation and laryngeal injury. Otolaryngol Head Neck Surg. 1994, 111(4):453-9.

12. PintoJA, Simon SP, Silva SNS. Granulomas inespecíficos da laringe. Rev Bras Otorrinolaringol. 1993, 59:253-6.

13. Kimaid PAT, Quagliato EMAB, Crespo AN, Wolf A, Viana MA, Resende LAL. Laryngeal electromyography in movement disorders. Arq Neuropsiquiatr. 2004, 62(3-A):741-4.

14. Hedden M, Ersoz CJ, Donnelly WH, Safar P. Laryngotracheal damage after prolonged use orotracheal tubes in adults. JAMA.1969, 207:703-08

15. Peppard S, Dickens J. Laryngeal injury following short term intubation. Ann Otol Rhinol Laryngol. 1983, 92:32730.

16. Keane W, Rowe L, Denneny J, Atkins J. Complications of intubation. Ann Otol Rhinol Laryngol. 1982, 91:584-7.

17. Hamdan AL, Sabra O, Rameh C, El-Khatib M. Persistant dysphonia following endotracheal intubation. M.E.J. Anesth. 2007, 19(1):5-14

18. Santos P, Afrassiabi A, Weymuller E. Prospective studies evaluating the standard endotracheal tube and a prototype endotracheal tube. Ann Otol Rhinol Laringol. 1989, 98:93540.

19. Balestrieri $\mathrm{F}$, Watson $\mathrm{CB}$. Intubation granuloma. Otolaryngol Clin North Am. 1982, 15:567-79.

20. Kikura M, Suzuki K, Itagaki T, Takada T, Sato S. Age and comorbidity as risk factors for vocal cord paralysis associated with tracheal intubation. British Journal of Anaesthesia. 2007, 98(4):524-30.

21. Sommer DD, Freeman JL. Bilateral vocal cord paralysis associated with diabetes mellitus: case reports. JOtolaryngol. 1994, 23:169-71 
22. Ajemian MS, Nirmul GB, Anderson MT, Zirlen DM, Kwasnik EM. Routine fiberoptic endoscopic evaluation of swallowing following prolonged intubation: implications for management. Arch Surg. 2001, 136(4):434-7.

23. Goldsmith T. Evaluation and treatment of swallowing disorders following endotracheal intubation and tracheostomy. Int Anesthesiol Clin. 2000, 38(3):219-42.

24. El Solh A, Okada M, Bhat A, Pietrantoni C. Swallowing disorders post orotracheal intubation in the elderly. Intensive Care Med. 2003, 29(9):1451-5.

25. Whited RE. Posterior commissure stenosis post longterm intubation. Laryngoscope. 1983, 93:1314-8.

26. Coelho MS, Stori Jr WS. Lesões crônicas da laringe pela intubação traqueal. J Pneumol. 2001, 27(2):68-76.

27. Kastanos N, Miro RE, Perez AM, Mir AX, Agusti-Vidal A. Laryngotracheal injury due to endotracheal intubation: incidence, evolution, and predisposing factors. A prospective long-term study. Crit Care Med. 1983, 11:362-7.

28. Kaneda N, Goto R, Ishijima S, Kawakami S, Park K, Shima Y. La-ryngeal granuloma caused by short-term endotracheal intubation. Anesthesiology. 1999, 90:1482-3.

29. Shimokojin T, Takenoshita M, Sakai T, Yoshikawa K. Vocal cord bowing as a cause of long-lasting hoarseness after a few hours of tracheal intubation. Anestesiology. 1998, 89:785-7.

30. Nordin U. The trachea and cuff-induced tracheal injury. An experimental study on causative factors and prevention. Acta Otolaryngol. 1977, 345(suppl):1-71.

31. Castilho EC, Braz JRC, Catâneo AJM, Martins RHG, Gregório EA, Monteiro ER. Efeito da pressão limite de 25 cmH2O e mínima de selo do balonete de tubos traqueais sobre a mucosa traqueal do cão. Rev Bras Anestesiol. 2003, 53:743-55.

32. Luna CM, Legarreta G, Esteva H, Laffaire E, Jolly EC. Effect of tracheal dilatation and rupture on mechanical ventilation using a low-pressure cuff tube. Chest. 1993, 104:639-40.

33. Navarro LHC, Braz JRC, Pletsh AK, Amorim RB, Módolo NSP. Estudos comparativos das pressões de balonetes de tubos traqueais, contendo ou não válvula geradora de pressão de Lanz. Rev Bras Anestesiol. 2001, 51:17-27.

34. Jackson C. Contact ulcer granuloma and other laryngeal complications of endotracheal anesthesia. Anesthesiology. 1953, 14: 425-36.
35. Weymuller E, Bishop M: Problems associated with prolonged intubation in the geriatric patient. Otolaryngol Clin N Amer. 1990, 23:1057-74.

36. Jones MW, Catling S, Evans E, Green DH, Green JR. Hoarseness after tracheal intubation. Anesthesia. 1992, 47:213-6.

37. Mencke T, Echternach M, Kleinschmidt S, Lux P, Barth V, Peter KP, Fuchs-BuderT. Laryngeal morbidity and quality of tracheal intubation. A randomized controlled trial. Anesthesiology. 2003, 98:1049-56.

38. Kunigk MRG, Chehter E. Disfagia orofaríngea em pacientes submetidos à entubação orotraqueal. Rev Soc Bras Fonoaudiol. 2007, 12(24):287-91.

39. Thomas R, Kumar EV, Kameswaran M, Shamim A, Ghamdii SA, mummigatty AP, et al. Post intubation sequelae in an intensive care unit. J Laryngol Otol. 1995, 109:3136.

40. Benjamin B. Prolonged intubations injuries of the larynx: endoscopic diagnosis, classification, and treatment. AnnOtol Rhinol Laringol. 1993, 102(Suppl 160):1-15.

41. Hamdan AL, Moukarbel RV, Farhat F, Obeid M. Vocal cord paralysis after open-heart surgery. Eur J Cardiothorac Surg. 2002, 21:671-4

42. Sasaki CT, Fukuda M, Kirchner JA. Laryngeal abductor activity in response to varying ventilatory resistance. Trans Am Acad OpthOtol. 1973, 77:403-10.

43. Laccourreye H, Chabolle F, Brasnu D, Saintguily JL. Les immobilités laryngées a près intubation. Ann Otolaryngol Chir Cervicofac. 1984, 101(4):253-9.

44. Pontes PAL, De Biase NG, Gadelha EC. Clinical evolution of laryngeal granulomas: treatment and prognosis. Laryngoscope. 1999, 109:289-94.

45. Shumrick KA, Shumrick DA, Vietti MJ. Inflamatory diseases of the larynx. In: FRIED, M. - The Larynx: a multidisciplinary approach. 2nd Ed. St Louis: Mosby. 1996. p. 283-306.

46. Porto AJS, Alves SN. Granuloma pós-entubação. Rev Bras Anestesiol. 1989, 39:43-5.

47. Pontes P, De Biase N, Kyrillos L, Pontes A. The importance of glottic configuration in the development of posterior granuloma. Ann Otol Rhinol Laryngol. 2001, 110:765-9.

48. Mota LAA, Sefer MPC, Costa dos Santos YM. Granuloma 
laríngeo-tratamento fonoterápico. Odontologia Clin Científ. Recife,2003, 2(3):229-32.

49. de Biase N, Master S, Pontes P, de Biase S. Granuloma posterior da laringe: evolução após injeção de botox. Rev Bras Otorrinolaringol. 2001, 67(4):557-61.

50. Whited RE. A prospective study of laryngotracheal sequelae in longterm intubation. Laryngoscope. 1984, 94:367-77.

51. Marshak G, Doyle WJ, Bluestore CD. Canine model of subglotic stenosis secondary to prolonged endotracheal intubation. Laryngoscope. 1982, 92(7):805-9.

52. Supance JS, Reilly JS, Doyle WJ, Bluestone CD, Hubbard J. Acquired subglottic stenosis following prolonged endotracheal intubation. A canine model. Arch Otolaryngol. 1982, 108(11):727-31.

53. Volpi D, Kurillof DB, Lin Pi-Tang, Kimmellaman CP. Risk factors for intubation injury of the larynx. Ann Otol Rhinol Laryngol. 1987, 96:684-6.
54. Montovani JC, Rui Jr RL, Castilho EC. Estenose subglótica. Rev Bras Otorrinolaringol. 1995, 61(2):97-102.

55. Cotton RT, Evans JN. Laryngotracheal reconstruction in children: five year follow-up. Ann Otol Rhinol Laryngol. 1981, 90(5):516-20.

56. PrescottCA. Protocol for management of the interposition cartilage graft laryngotracheoplasty. Ann Otol Rhinol Laryngol. 1988, 97(3):239-42.

57. Seid AB, Pransky SM, Kearns DB. One stage laryngotracheoplasty. Arch Otola-ryngol Head Neck Surg. 1991, 117(4):408-10.

58. Ranne RD, Lindley S, Holder TM, Ashcraft KW, Sharp RJ, Amoury RA. Relief of subglottic stenosis by anterior cricoid resection: an operation for the difficult case. J Pediatr Surg. 1991, 26(3):255-8.

59. Anand VK, Alemar G, Warren ET. Surgical considerations in tracheal stenosis. Laryngoscope. 1992, 102(3):237-43. 